\title{
Verb Collocations in Medical English
}

\author{
Bionote Evelina Miščin \\ College of Business and Management, Zagreb, Croatia
}

\begin{abstract}
The aim of this paper was to investigate the most frequent verb collocations which occur in medical texts and to check the competence of the first-year students of medical English in using them. Merck's Manual of Medical Information (2004) was used as a corpus to find the most frequent collocations. It was analyzed by several programmes like Simple Concordance, Collocation Extract, TermeX. The corpus analysis established that the nouns "function" and "infection" occur with most verbs (30). They are followed by "pain" (28 verbs), "muscle" (24 verbs). Three hundred and sixty-two verbs occur with nouns and among them the most frequent are "cause", "have", "develop", "treat", "prevent", and "produce". After that, the test was devised to see which collocations students use with the most competence. Two hundred and ninety-seven first-year students of School of Medicine in Zagreb were tested. There were four types of exercises - multiple choice, gap-fill, translation from English into Croatian, and vice versa. The average result in multiple choice was 9.8 with the $s=2.0$ as a standard deviation, in gap-fill 5.0 with $s=2.17$, in translation into Croatian 6.7 with $s=2.10$, and in translation into English 5.2 with $s=2.53$. Then, glossary was made which should help future users of medical English.
\end{abstract}

Keywords: collocations, collocational competence, corpus, collocational mistakes, glossary

\section{Introduction}

This paper deals with verb collocations in medical English. The term collocation was first used by Firth in the 1950s, but only few linguists researched this phenomenon in the scientific English. Previous researches were mostly focused on collocations in general English (Channel, 1981; Elkhatib, 1984; Ghadessy, 1989; Aghbar, 1990; Aghbar \& Tang, 1991; Fayez-Hussein, 1990; Bahns \& Eldaw, 1993; ZHANG, 1993; Arnaud \& Savignon, 1994; Gitsaki, 1999). The scientific English collocations were dealt by Gledhill (2000), and in Croatia by Špiranec (2005-technical English) and by Štefić, Mravak-Stipetić, and Borić (2010 - dental medical English).

Only a brief review of the linguistic theory of collocations will be given. Next, the corpus consisting of over a million words will be described. Nouns will be extracted in order to obtain their verb collocations. The glossary will be made consisting of 500 most frequent nouns and their collocations. Here, instead of the glossary the list of most frequent nouns with their verb collocations is given. The next step will see to what extent medical students recognise these collocations and what are the most frequent mistakes they make. The conclusion will help in eliminating such mistakes in future.

Bionote Evelina Miščin, senior lecturer, Department of Foreign Languages, College of Business and Management. 


\section{Theory of Collocations}

A collocation refers to a multi-word combination. It can consist of two or more words. The interest for such combinations started in the last two decades under different names e.g., phrasemes, idioms, fixed expressions, formulaic language, co-selection of words, and phrasal lexemes (Omazić, 2003, p. 13). The term collocation was introduced by Firth in the 1950s. The name derives from Latin (com together + locare locate). The definition of a collocation is that it is a multi-word construct which occurs in a procedure of locating, i.e., co-occurrence or combination of words on the syntagmatic level. Thus, Firth tried to explain collocations by syntagmatic and paradigmatic relation between lexical units which can be shown by two axes-horizontal and vertical. Paradigmatic axis is vertical and includes words which belong to the same class and can be inter-changed. Horizontal axis is syntagmatic and refers to the ability of words to be connected with the others. For instance, in a sentence "Mary drank beer", beer is in a paradigmatic relation to wine, juice, Coke and in syntagmatic with drank and Mary. There are different theories of collocations since the topic of this paper is not the linguistic one, but its application in practice, it will not be further dealt with. This paper will deal with lexical collocations, i.e., word combinations consisting of a verb and a noun and so-called upward collocations (Sinclair, 1991, pp. 115-116) where $a$ is a collocate and $b$ node.

\section{Collocations and Non-native Speakers}

Collocations usually represent a huge problem to non-native speakers due to interference with their mother tongue. That is why Hill (1999) suggested the creation of a term "collocational competence" and insisted on acquiring not just the total meaning of a word, but also its collocational span. Collocational competence was also emphasised by some other researchers (Nattinger \& DeCarrico, 1992; Lewis, 1993; Woolard, 2000). They think it contributes to better understanding of difficulties encountered by language learners. The importance of acquiring collocations in language teaching has been particularly emphasised in the last two decades. Researches have also shown that mistakes in collocations are the most frequent mistakes made by non-native speakers (James, 1998). James also quoted McCretton and Rider, and gave their hierarchical order of mistakes (James, 1998, p. 229).

The Most Serious $\quad$ The Least Serious

Lexis $>$ spelling $>$ negation $>$ word order $>$ prepositions $>$ verb forms $>$ concord

Figure 1. Hierarchy of mistakes according to McCretton and Rider. Source: Adapted from James (1998, p. 229).

From Figure 1, it can be seen that lexical mistakes are the most serious ones. A speaker can be understood if he/she makes a grammatical mistake. However, if he/she makes a lexical mistake there could be misunderstanding and the same problem occurs with mistakes in collocations. That is why it is important to teach collocations.

\section{Method}

In order to analyze collocations, it was necessary to have a corpus. The corpus for this research was based on the online version of Merck's Manual of Medical Information (2004). The files contained 1,065,181 items and included all organ systems. Then, the most frequent words, i.e., salient words were established. Next, it was important to establish a criterion for determining collocations and follow their frequency. Common words, i.e., 
function/structure words were eliminated leaving content/lexical words, in this case medical words. The corpus was processed by three programmes: Simple Concordance, Collocation Extract, and TermeX. After that, the glossary which included most frequent collocations was made with the Croatian translation. It was followed by testing of collocational competence. The test was devised which included different frequency collocations. The results were analyzed and the conclusion was made.

\section{Results and Discussion}

Corpus analysis established that the first content/lexical word appeared in the 17th place. The most frequent word is a noun "blood". The glossary with 500 most frequent nouns was made. It was also analyzed how many times each noun occurred with some collocations. Some nouns like "anus", "apnoea", and "aspirin" occur with only one verb while nouns like "function" and "infection" occur with even 30 verbs. Regarding verbs, some like "abort", "absorb", and "allow" occur only once in the corpus as a collocate and the most frequent ones are "cause", "have", "develop", "treat (with)", "prevent”, and "produce". Verbs are also classified into three groups: verbs which diagnose illnesses (conditions) (e.g., "assess", "check", "evaluate”, and "diagnose”), verbs which increase the negativity (e.g., "cause", "provoke", and "inflict") and verbs which decrease the negativity (e.g., "alleviate", "decrease", "reduce", and "relieve"). It was thought that such a classification would make the use of collocations easier and show which synonyms could be used.

The next step was to determine the competence of verb collocations of the first-year students of medical English. The idea was to get insight into the problems that collocations cause, either in understanding or in the use and based on the results, suggest possible ideas for making the glossary of most frequent verb collocations.

Two hundred and ninety-seven subjects participated in the research. The sex distribution of subjects can be seen in Table 1.

Table 1

Sex Distribution of Subjects

\begin{tabular}{lrr}
\hline & N & $\%$ \\
\hline M & 109 & 36.7 \\
$F$ & 187 & 63.0 \\
No answer & 1 & 0.3 \\
\hline Total & 297 & 100.0 \\
\hline
\end{tabular}

English is obligatory at the School of Medicine, but the number of years students had studied it differs and can be seen in Table 2 .

Table 2

The Number of Years of Studying English

\begin{tabular}{lrr}
\hline Years of studying & $\mathrm{N}$ & $\%$ \\
\hline $0-4$ & 22 & 7.5 \\
$5-10$ & 145 & 48.8 \\
$11-15$ & 116 & 39.1 \\
16 & 1 & 0.3 \\
No answer & 13 & 4.4 \\
\hline Total & 297 & 100.0 \\
\hline
\end{tabular}


It was the first year of medical English for those students. Their level of knowledge of English after the secondary school was B2, so they had competence of general English language. In this way, the problems at the beginning of studying English medical language could have been diagnosed. It should have helped in making a glossary and in deciding which collocations should be introduced in class. The test was written after 18 lessons. It consisted of four groups of tasks. Each task had fifteen questions which makes the total of 60 questions (see Appendix). The first group tested the receptive level of collocation competence and included multiple choice questions. Two groups of questions tested productive level and included gap-fill and translation from Croatian into English. The last group of questions refers to productive-receptive level since the subjects had to recognise the meaning of the collocation in English and offer its translation. Collocations used for the test were chosen based on two criteria: (1) corpus frequency; and (2) semantic field. Also, collocations of various frequency spans were chosen and they appear in the corpus from one to 48 times.

Students were tested during regular classes at the School of Medicine in Zagreb. They were given instructions in Croatian and they had 60 minutes for answers.

The maximum number of points for each group of questions was 15 , which made the total of 60 points. Each correct answer was given one point. In translations only the underlined collocations were evaluated. It was not important whether students would translate other sentence parts. Also, grammatical competence and spelling were not evaluated. Results of testing were analyzed by SPSS (Statsistical Package for Social Sciences) programme and can be seen in Table 3.

Table 3

Results of Testing

\begin{tabular}{llllll}
\hline & N & Min. & Max. & M & Std. \\
\hline I. Circle the correct answer & 297 & 4 & 14 & 9.8 & 2.00 \\
II. Put the verbs in the gaps & 297 & 0 & 12 & 5.0 & 2.17 \\
III. Translate into Croatian & 297 & 1 & 12 & 6.7 & 2.10 \\
IV. Translate into English & 297 & 0 & 11 & 5.2 & 2.53 \\
\hline
\end{tabular}

As it can be seen from Table 3, the best results were obtained in the first part of the test-multiple choice. The average results was 9.8 points with the standard deviation $s=2.0$. The translation from English into Croatian was a bit more difficult where the average number of points was 6.7 with $s=2.1$. Gap fill $(\mathrm{M}=5.0$ with $s=2.17)$ and the translation into English ( $\mathrm{M}=5.2$ with $s=2.5)$ were equally difficult for students. It can be concluded that receptive level tasks were easier for students than productive level ones. The difference between the receptive, productive-receptive and productive level was checked with dependent samples $t$-test and can be seen in Table 4 .

Table 4

Differences Between the Receptive and Productive-Receptive Level and Receptive and Productive Level for Individual Tasks

\begin{tabular}{lllllll}
\hline Differences between task groups & Difference M & Std. v & Standard difference mistake & $t$ & $d f$ & $p$ \\
\hline I i II & 4.74 & 2.48 & 0.137 & 32.96 & 296 & 0.000 \\
I i III & 3.05 & 2.38 & 0.138 & 22.12 & 296 & 0.000 \\
I i IV & 4.60 & 2.59 & 0.150 & 30.56 & 296 & 0.000 \\
\hline
\end{tabular}


As it can be seen from Table 4 that differences among the tasks are statistically significant, and it is again proved that the receptive level tasks are easier for students.

In Table 5, it can be seen which collocations have caused most mistakes.

Table 5

Summary of Testing Results

\begin{tabular}{|c|c|c|c|c|}
\hline Collocation & $\begin{array}{l}\text { Frequency of occurrence } \\
\text { in the corpus (times) }\end{array}$ & Croatian translation & $\begin{array}{l}\text { Most frequent wrong } \\
\text { translation of students }\end{array}$ & $\begin{array}{l}\text { Percentage of } \\
\text { collocational } \\
\text { competence }(\%)\end{array}$ \\
\hline Respond to treatment & 14 & Reagirati na liječenje & Answer to treatment & 31.6 \\
\hline Receive a kidney & 3 & Dobiti bubreg & Obtain a kidney & 95.3 \\
\hline Aggravate the injury & 1 & Pogoršati ozljedu & Deteriorate the injury & 54.9 \\
\hline Replace the hip & 2 & Zamijeniti kuk & Exchange the hip & 89.6 \\
\hline Gain weight & 18 & Dobiti na težini & Get weight & 72.9 \\
\hline Contract malaria & 1 & Dobiti malariju & Obtain malaria & 43.1 \\
\hline Establish the diagnosis & 6 & Utvrditi dijagnozu & Do the diagnosis & 81.8 \\
\hline Tolerate pain & 2 & Podnositi bol & Suffer pain & 92.6 \\
\hline $\begin{array}{l}\text { Perform physical } \\
\text { examination }\end{array}$ & 19 & $\begin{array}{l}\text { Obaviti/izvršiti fizikalni } \\
\text { pregled }\end{array}$ & Do physical examination & 56.2 \\
\hline $\begin{array}{l}\text { Maintain physical } \\
\text { fitness }\end{array}$ & 3 & $\begin{array}{l}\text { Održavati tjelesnu } \\
\text { spremnost }\end{array}$ & Sustain physical fitness & 73.1 \\
\hline Predict a prognosis & 1 & Pretpostaviti prognozu & Foresee prognosis & 44.4 \\
\hline Feel the pulse & 1 & Opipati puls & Test the pulse & 49.2 \\
\hline Provide relief & 48 & Pružiti olakšanje & Give relief & 79.1 \\
\hline Pose the risk & 21 & Predstavljati rizik & Represent risk & 39.1 \\
\hline Loosen the secretion & 5 & Razrijediti izlučevinu & Lessen/weaken the secretion & 26.3 \\
\hline $\begin{array}{l}\text { Refrain from/avoid } \\
\text { alcohol consumption }\end{array}$ & $1 / 1$ & $\begin{array}{l}\text { Izbjegavati uzimanje } \\
\text { alkohola }\end{array}$ & Stop alcohol consumption & $0.0 / 51.8$ \\
\hline Change the bandage & 1 & Promijeniti zavoj & Replace the bandage & 20.9 \\
\hline Develop a bedsore & 2 & Dobiti dekubitus & Appear a bedsore & 7.7 \\
\hline Take blood samples & 19 & Uzeti krvni uzorak & Send blood samples & 44.3 \\
\hline Relieve pain & 108 & Ublažiti bol & Stop pain & 24.0 \\
\hline Treat the infection & 35 & Liječiti infekciju & Stop the infection & 6.3 \\
\hline $\begin{array}{l}\text { Sustain/experience the } \\
\text { injury }\end{array}$ & $2 / 1$ & Pretrpjeti ozljedu & Suffer the injury & $1.6 / 3.4$ \\
\hline Seek medical attention & 13 & Tražiti liječničku pomoć & Ask for medical attention & 12.8 \\
\hline Undergo/have surgery & $33 / 17$ & $\begin{array}{l}\text { Podvrgnuti se kirurškom } \\
\text { zahvatu }\end{array}$ & Perform surgery & $10.4 / 50.0$ \\
\hline $\begin{array}{l}\text { Administer/give } \\
\text { penicillin }\end{array}$ & $1 / 4$ & Dati penicilin & Prescribe penicillin & $3.7 / 54.1$ \\
\hline $\begin{array}{l}\text { Check/ take } \\
\text { temperature }\end{array}$ & 3 & Provjeriti temperaturu & Measure temperature & 14.4 \\
\hline $\begin{array}{l}\text { Carry out/perform } \\
\text { check-ups }\end{array}$ & 1 & Izvršiti pregled & Do the check up & 0.0 \\
\hline $\begin{array}{l}\text { Catch/pick up the flu } \\
\text { bug }\end{array}$ & $1 / 1$ & Pokupiti virus gripe & Get the flu bug & $26.0 / 1.7$ \\
\hline Regain consciousness & 1 & $\begin{array}{l}\text { Doći k svijesti/povratiti } \\
\text { svijest }\end{array}$ & Osvijestiti & 41.4 \\
\hline Induce vomiting & 5 & $\begin{array}{l}\text { Izazvati/inducirati } \\
\text { povraćanje }\end{array}$ & Potaknuti povraćanje & 42.5 \\
\hline Go into shock & 6 & Pasti u šok & Doživjeti šok & 58.9 \\
\hline Extend survival & 1 & Produžiti život & Produžiti preživljavanje & 81.1 \\
\hline
\end{tabular}


(Table 5 continued)

\begin{tabular}{|c|c|c|c|c|}
\hline Collocation & $\begin{array}{l}\text { Frequency of occurrence } \\
\text { in the corpus (times) }\end{array}$ & Croatian translation & $\begin{array}{l}\text { Most frequent wrong } \\
\text { translation of students }\end{array}$ & $\begin{array}{l}\text { Percentage of } \\
\text { collocational } \\
\text { competence }(\%) \\
\end{array}$ \\
\hline Produce pain & 3 & $\begin{array}{l}\text { Izazvati/prouzrokovati } \\
\text { bol }\end{array}$ & Proizvesti bol & 93.0 \\
\hline Strain the back & 1 & Istegnuti leđa & Ozlijediti leđa & 68.4 \\
\hline Eradicate infections & 1 & $\begin{array}{l}\text { Iskorijeniti/ istrijebiti } \\
\text { infekcije }\end{array}$ & Protiv infekcija & 6.1 \\
\hline Suppress inflammation & 3 & $\begin{array}{l}\text { Suzbijati/potiskivati } \\
\text { upalu }\end{array}$ & Sprječavati upalu & 19.6 \\
\hline Undergo dialysis & 2 & $\begin{array}{l}\text { Podvrgnuti se dijalizi/ići } \\
\text { na dijalizu }\end{array}$ & Podliježu dijalizi & 56.2 \\
\hline Develop kidney stone & 1 & $\begin{array}{l}\text { Dobiti bubrežne } \\
\text { kamence/oboljeti od } \\
\text { bubrežnih kamenaca }\end{array}$ & Razviti bubrežne kamence & 23.3 \\
\hline Detect a lump & 1 & Otkriti/detektirati kvržicu & Osjetiti kvržicu & 54.2 \\
\hline Impair memory & 2 & $\begin{array}{l}\text { Pogoršati } \\
\text { pamćenje/štetno utjecati } \\
\text { na pamćenje }\end{array}$ & Oštetiti memoriju & 19.1 \\
\hline $\begin{array}{l}\text { Abort migraine } \\
\text { headaches }\end{array}$ & 3 & $\begin{array}{l}\text { Zaustaviti migrenske } \\
\text { glavobolje }\end{array}$ & Prekinuti migrenske bolove & 23.0 \\
\hline Relieve nausea & 4 & $\begin{array}{l}\text { Ublažiti/olakšati } \\
\text { mučninu }\end{array}$ & Smanjiti mučninu & 21.6 \\
\hline Speed the onset & 1 & $\begin{array}{l}\text { Ubrzati pojavu/početak/ } \\
\text { javljanje }\end{array}$ & Ubrzati & 21.8 \\
\hline Tolerate a drug & 1 & Podnositi lijek & Respond well to medicine & 10.1 \\
\hline Catch a cold & 1 & Prehladiti se & Get cold & 39.6 \\
\hline Detect a cancer & 10 & Otkriti rak & Discover a cancer & 15.7 \\
\hline $\begin{array}{l}\text { Cleanse/clean the } \\
\text { wound }\end{array}$ & $2 / 1$ & Očistiti ranu & Disinfect the wound & $73 / 0$ \\
\hline Transmit a disease & 17 & Prenositi bolest & Transfer a disease & 21.3 \\
\hline Get/develop symptoms & $11 / 47$ & Dobiti simptome & Gain symptoms & $63.6 / 4.7$ \\
\hline Identify antibodies & 1 & Utvrditi antitijela & Determine antibodies & 0.0 \\
\hline Ease/relieve anxiety & $1 / 5$ & Ublažiti tjeskobu & Suppress anxiety & $0.0 / 19.3$ \\
\hline $\begin{array}{l}\text { Enhance/increase the } \\
\text { appetite }\end{array}$ & 1 & Povećati apetit & Improve the appetite & $1.0 / 38.5$ \\
\hline Precipitate the attack & 1 & Pospješiti napad & Induce the attack & 0.0 \\
\hline Suppress a cough & 4 & Suzbiti kašalj & Prevent cough & 25.0 \\
\hline $\begin{array}{l}\text { Produce/cause } \\
\text { discomfort }\end{array}$ & $1 / 16$ & Izazvati nelagodu & Cause unease & $0.0 / 1.7$ \\
\hline Trigger diseases & 1 & Potaknuti bolesti & Induce diseases & 2.4 \\
\hline Admit to hospital & 17 & Primiti u bolnicu & Take in the hospital & $16.2 / 3.7$ \\
\hline $\begin{array}{l}\text { Produce/cause } \\
\text { improvement }\end{array}$ & $1 / 1$ & Izazvati poboljšanje & Make improvement & $1.3 / 18.9$ \\
\hline
\end{tabular}

From Table 5, it can be seen that the students most frequently made mistakes in collocations "produce discomfort", "identify antibodies", "sustain/experience the injury", and "precipitate attack". Most mistakes were made in collocations which belong to the semantic field of increasing negative effects, then in collocations from the semantic field of decreased negativity and the least in collocations for diagnosing illnesses. Sometimes, students do not know collocations in their own mother tongue, so this paper suggests the importance of teaching not just collocations in English, but also in the Croatian language for special purposes. 


\section{Conclusions}

This paper dealt with verb collocations in medical English. Their significance is emphasised since they represent the connection between words on one side and the text on the other. The aim of the research was to establish the most frequent verb collocations in medical English, most frequent mistakes that students make and to make a glossary with most frequent verb collocations. It was established that nouns "function" and "infection" occur with most verbs (30), followed by "pain" (28 verbs) and "muscle" (24 verbs). It was also established that 362 verbs occur forming the collocation with nouns. The most frequent ones are "cause" (130 times), "have" (113 times), "develop" (93 times), "treat" (79 times alone and 16 times as a phrasal verb "treat with"), "prevent" (77 times), and "produce" (57 times). Verbs were also classified according to semantic fields in order to try to explain why certain verbs occur with a certain noun in a collocation. Then, the test was devised based on the glossary. The collocational competence of 297 first-year medical students was tested in the year 2009/2010. Four types of tasks were used: multiple choice, gap-fill, translation from English into Croatian, and vice versa. The final aim of this research was to indicate the need for acquiring collocations which are the important aspect of L2 (second language) performance. If it is known which types of collocations cause problems at a certain level, teachers can gradually introduce such collocations in order to develop collocational competence. Since there are no good dictionaries of collocations, the glossary was made based on the corpus and analyzed mistakes. It should help medical students, doctors, nurses, translators, and anybody using medical English.

\section{References}

Aghbar, A. A. (1990). Fixed expressions in written texts: Implications for assessing writing sophistication. Paper presented at a Meeting of the English Association of Pennsylvania State System Universities.

Aghbar, A. A., \& Tang, H. (1991). Partial credit scoring of cloze-type items (pp. 1-24). Paper presented at 1991 Language Testing Research Colloquium, Educational Testing Service, Princeton, N.J..

Arnaud, P. J. L., \& Savignon, S. S. (1994). Rare works, complex lexical units and the advanced learner. In J. Coady \& T. Huckin (Eds.), Second language vocabulary acquisition: A rationale for pedagogy. Cambridge: Cambridge University Press

Bahns, J., \& Eldaw, M. (1993). Should we teach EFL students collocations?. System, 21(1), 104-114.

Blagus Bartolec, G. (2008). Collocations in Croatian (with a special reference to lexicography) (Kolokacijske sveze u hrvatskom jeziku (s posebnim osvrtom na leksikografiju)) (Doctoral thesis, Faculty of Humanities and Social Sciences, University in Zagreb, Zagreb).

Channell, J. (1981). Applying semantic theory to vocabulary teaching. English Language Teaching Journal, 35, 115-122.

Chen, P. C. (2002). A corpus-based study of the collocational errors in the writings of the EFL learners in Taiwan (Master thesis, National Taiwan Normal University, Taiwan).

Cobb, T. (2005). Collocations in a learner corpus (Review of Nadja Nesselhauf). Studies in corpus linguistics, 14.

Douglas, D. (2000). Assessing languages for specific purposes. Cambridge: Cambridge University Press

Elkhatib, A. S. A. (1984). A classification of the lexical problems of EFL/ESL students. New York, U.S.: Reports-Research/Technical

Ellis, N. C. (2008). Phraseology: An interdisciplinary perspective (pp. 1-13). F. Meunier \& S. Granger (Eds.). Amsterdam: John Benjamins Publishing Co..

Fayez-Hussein, R. (1990). Collocations: The missing link in vocabulary acquisition amongst EFL learners. In J. Fisiak (Ed.), Papers and studies in contrastive linguistics: The Polish English contrastive project, 26 (pp. 123-136). Poznan: Adam Mickiewicz University.

Firth, J. R. (1957). Papers in linguistics 1934-1951. Oxford: Oxford University Press.

Gavioli, L. (2005). Exploring corpora for ESP learning. Amsterdam: John Benjamins.

Ghadessy, M. (1989). The use of vocabulary and collocations in the writing of primary school students in Singapore. In P. Nation \& R. Carter (Eds.), Vocabulary acquisition (pp. 110-117). AILA Review, 6. 
Gitsaki, C. (1999). Second language lexical acquisition: A study of the development of collocational knowledge. San Francisco: International Scholars Publications.

Gledhill, C. J. (2000). Collocations in science writing. Tübingen: Günter Narr Verlag.

Hill, J. (1999). Collocational competence. ETP, 11.

Hoey, M. (2005). Lexical priming: A new theory of words and language. London: Routledge

Ivančević, Ž. (Ed.). (2002). MSD medical handbook (MSD medicinski priručnik). Split: Placebo d.o.o..

Jaén, M. M. (2007). A corpus-driven design of a test for assessing the ESL collocational competence of university students. International Journal of English Studies, 7(2), 127-147

James, C. (1998). Errors in language learning and use: Exploring error analysis. Harlow: Pearson.

Lewis, M. (1993). The lexical approach. London: Language Teaching Publications.

Meunier, F., \& Granger, S. (Eds.). (2008). Phraseology: An interdisciplinary perspective. Amsterdam: John Benjamins Publishing Co..

Milton, J. (2009). Measuring second language vocabulary acquisition. Bristol: Multilingual Matters.

Miščin, E. (2012). Verb collocations in English (Glagolske kolokacije u engleskome jeziku) (Unpublished doctoral thesis, Faculty of Humanities and Social Sciences, University in Osijek, Osijek).

Nation, I. S. P. (2001). Learning vocabulary in another language. Cambridge: Cambridge University Press

Nattinger, J. R., \& DeCarrico, S. J. (1992). Lexical phrases and language teaching. Oxford: Oxford University Press.

Neselhauf, N. (2003). The use of collocations by advanced learners of English and some implications for teaching. Applied Linguistics, 24(2), 223-242

Omazić, M. (2003). Modifications of phraseological units in English: A dissertation. Zagreb: Filozofski fakultet u Zagrebu.

Sinclair, J. (1991). Corpus, concordance, collocation. Oxford: Oxford University Press.

Špiranec, I. (2005). Nature and use of collocations: Examples from the technical English (Priroda i upotreba kolokacija: Primjeri iz tehničkoga engleskoga jezika). Strani Jezici, 34(3), 219-227.

Štefić, L., Mravak-Stipetić, M., \& Borić, V. (2010). Collocations in the language of dental medicine: Examples from the oral medicine (Kolokacije u jeziku stomatologije: Primjeri iz oralne medicine). Acta Stomatologica Croatica, 44(3), 176-187.

WEI, N. (2002). The definition and research system of the word collocation. Shanghai: Shanghai Jiaotong University Press.

Woolard, G. (2000). Collocation-Encouraging learner independence. In M. Lewis (Ed.), Teaching collocation: Further developments in the lexical approach (pp. 28-46). Hove: Language Teaching Publications.

YUE, Q. (2005). An error analysis of advanced leamer's lexical collocation in writing-A corpus-based study (Dissertation, Shanghai International Studies University, Shanghai).

ZHANG, X. (1993). English collocations and their effect on the writing of native and non-native college freshmen (Unpublished Ph.D. thesis, Indiana University of Pennsylvania).

\section{Appendix: Text}

Sex:

Town you come from:

Years of learning English:

I Circle the correct answer:
(1) She is well to treatment.
(a) responding
(b) answering
(c) recovering

(2) $\mathrm{He}$ a new kidney from his brother.
(a) had
(b) received
(c) obtained

(3) Playing football only his knee injury.
(a) impaired
(b) deteriorated
(c) aggravated

(4) The doctors the patient's hip. 

(a) changed
(b) replaced
(c) exchanged

(5) Some people want and need to weight.
(a) get
(b) gain
(c) grow

(6) My uncle malaria when he was working in Africa.
(a) contracted
(b) obtained
(c) received

(7) The doctor the diagnosis of heart failure.
(a) performed
(b) did
(c) established

(8) The ability to pain may change with age.
(a) suffer
(b) tolerate
(c) experience

(9) Each doctor will physical examination in different orders.
(a) do
(b) make
(c) perform

(10) The authors recommend a wide range of foods to
(a) maintain
(b) hold
(c) sustain physical fitness.

(11) Similar procedures may be used to a person's prognosis after a heart attack.
(a) predict
(b) foresee
(c) determine

(12) The doctor the pulse in arteries in the neck, beneath the arms...
(a) feels
(c) touches
(c) tests

(13) Antacids relief more quickly than $\mathrm{H} 2$ blockers.
(a) give
(b) offer
(c) provide

(14) Respirators can
(a) represent
(b) show

some risk for people with heart or lung ailments.

$\begin{array}{lll}\text { (15) Steam inhalation can effectively } & \text { secretion. } \\ \begin{array}{lll}\text { (a) weaken } & \text { (b) loosen } & \text { (c) lessen }\end{array}\end{array}$

II Put the verbs in the gaps:

(1) When you are pregnant you should ___ alcohol consumption.

(2) The bandage should be regularly.

(3) A bedsore can in hours and may take months to heal.

(4) Each time you give blood a doctor__ blood samples for safety tests in the labs.

(5) The ECG (electrocardiogram) is an important and sometimes central tool used to the diagnosis of myocardial ischemia.

(6) NSAIDs are often used to headache pain.

(7) The patient was to hospital due to terrible injury.

(8) Antibiotics are used to

(9) He has severe head injury.

(10) If you experience a severe allergic reaction e.g. with breathing difficulty

(11) Tony Snow will surgery on Monday to remove a small growth. medical attention urgently.

(12) The doctor wil penicillin or other antibiotics by pill or by injection.

(13) The task of a nurse is also to a patient's temperature.

(14) Health visitors visit families to check-ups on young children. 
(15) I think I've ___ the flu bug that's going round.

III Translate into Croatian. Pay special attention to underlined words:

(1) The victim regained consciousness after 2 months of coma.

(2) You should induce vomiting.

(3) A person can quickly go into shock and die because of internal bleeding.

(4) Chemotherapy can sometimes extend survival to 8 months.

(5) Deep breathing may produce pain.

(6) He strained his back lifting the table.

(7) Treatment is directed against eradicating infections.

(8) Glucocorticoids suppress inflammation in the human placenta.

(9) Over two hundred thousand Americans undergo kidney dialysis.

(10) There is a higher percentage for men to develop kidney stone than women.

(11) She detected a lump in her left breast.

(12) Smoking in midlife may impair memory.

(13) Some medications can abort migraine headaches.

(14) Vomiting relieves nausea right away.

(15) Alcohol can speed the onset of hypothermia.

IV Translate into English. Pay special attention to underlined words:

(1) Dobro podnosi lijek.

(2) Noge su mi bile mokre, pa sam se prehladila.

(3) Mamografija se koristi za otkrivanje raka dojke.

(4) Ranu treba dobro očistiti.

(5) Komarci mogu prenositi bolesti.

(6) Neki ljudi dobiju simptome kao djeca.

(7) Krvni testovi utvrđuju određena antitijela.

(8) Obično se daje sedativ za ublažavanje tjeskobe.

(9) Lijekovi mogu povećati apetit.

(10) Emocionalni stress često pospješuje napad.

(11) Antitusici suzbijaju kašalj.

(12) Dim može izazvati nelagodu respiratornog sustava.

(13) Stres može potaknuti različite bolesti.

(14) Primljen je u bolnicu zbog ozbiljne ozljede.

(15) Ovi lijekovi mogu izazvati poboljšanje za nekoliko mjeseci. 